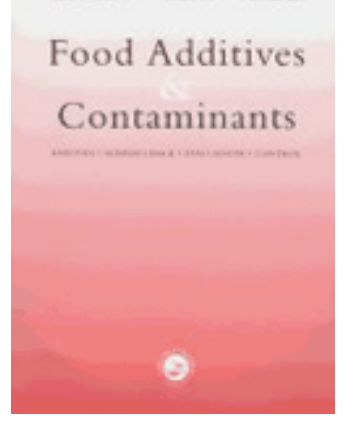

\title{
CO-OCCURRENCE OF AFLATOXIN B1, FUMONISIN B1, OCHRATOXIN A AND ZEARALENONE IN CEREALS AND PEANUTS IN COTE D'IVOIRE
}

\begin{tabular}{|r|l|}
\hline Journal: & Food Additives and Contaminants \\
\hline Manuscript ID: & TFAC-2005-252.R1 \\
\hline Manuscript Type: & Original Research Paper \\
\hline Author: & 11 -Oct-2005 \\
\hline Complete List of Authors: & $\begin{array}{l}\text { SANGARE-TIGORI, Béatrice; University of Bordeaux 2, Toxicology } \\
\text { MOUKHA, Serge; INRA, MycSA } \\
\text { KOUADIO, James; University of Bordeaux 2, Toxicology } \\
\text { BETBEDER, Anne-Marie; University of Bordeaux 2, Toxicology } \\
\text { DANO, Sébastien; University of Abidjan Cocody, Toxicology } \\
\text { CREPPY, Edmond; University Bordeaux 2, Toxicology }\end{array}$ \\
\hline Methods/Techniques: & $\begin{array}{l}\text { Survey, Chromatography - HPLC, Clean-up - affinity columns, } \\
\text { Immunoassays }\end{array}$ \\
\hline Additives/Contaminants: & $\begin{array}{l}\text { Mycotoxins, Aflatoxins, Mycotoxins - ochratoxin A, Mycotoxins - } \\
\text { fusarium }\end{array}$ \\
\hline Food Types: & Peanuts, Rice, Cereals and grain \\
\hline
\end{tabular}

\section{SCHOLARONE \\ Manuscripts}


Table 1: Different mycotoxins assayed and detected in the same commodities in Côte d'Ivoire

\begin{tabular}{|l|c|c|c|}
\hline \multicolumn{1}{|c|}{ Mycotoxins } & \multicolumn{3}{|c|}{ Food samples } \\
\cline { 2 - 4 } & Maize & Rice & Peanuts \\
\hline Aflatoxin B1 & $\mathrm{n}=10$ & $\mathrm{n}=10$ & $\mathrm{n}=10$ \\
$(\mu \mathrm{g} / \mathrm{kg})$ & $<1.5-20$ & $<1.5-10$ & $1.5-10$ \\
Range (positive \%) & $(100 \%)$ & $(100 \%)$ & \\
& & & $\mathrm{n}=100 \%)$ \\
\hline Fumonisin B1 & $\mathrm{n}=10$ & Not detected & $<0.3-6$ \\
$(\mathrm{mg} / \mathrm{kg})$ & $0.3-1.5$ & & $(70 \%)$ \\
Range (positive \%) & $(100 \%)$ & & $\mathrm{n}=10$ \\
& & $\mathrm{n}=10$ & $0.0-0.64$ \\
\hline Ochratoxin A & $\mathrm{n}=10$ & $0.16-0.92$ & $(60 \%)$ \\
$(\mu \mathrm{g} / \mathrm{kg})$ & $0.16-0.86$ & $(100 \%)$ & $\mathrm{n}=10$ \\
Range (positive \%) & $(100 \%)$ & & $50-200$ \\
& & $\mathrm{n}=10$ & $(100 \%)$ \\
\hline Zearalenone & $\mathrm{n}=10$ & $50-200$ & \\
$(\mu \mathrm{g} / \mathrm{kg})$ & $20-50$ & $(100 \%)$ & \\
Range (positive \%) & $(100 \%)$ & & \\
& & & \\
\hline
\end{tabular}


Table 2: Concentrations of aflatoxin B1, fumonisin B1, ochratoxin A and zearalenone detected in maize samples, $(n=10)$

\begin{tabular}{|l|l|l|l|l|l|l|l|l|l|l|}
\hline \multirow{2}{*}{ Mycotoxins } & \multicolumn{10}{|c|}{ Maize samples } \\
\cline { 2 - 11 } & 1 & 2 & 3 & 4 & 5 & 6 & 7 & 8 & 9 & 10 \\
\hline $\begin{array}{l}\text { Aflatoxin } \\
\text { B1 }(\mu \mathrm{g} / \mathrm{kg})\end{array}$ & 1.5 & $<1.5$ & 1.5 & 1.5 & 1.5 & $<1.5$ & 5 & 5 & 1.5 & 20 \\
\hline $\begin{array}{l}\text { Fumonisin } \\
\text { B1 }(\mathrm{mg} / \mathrm{kg})\end{array}$ & 1.5 & 0.3 & 0.3 & 1.5 & 1.5 & 0.3 & 0.3 & 1.5 & 0.3 & 1.5 \\
\hline $\begin{array}{l}\text { Ochratoxin } \\
\mathrm{A}(\mu \mathrm{g} / \mathrm{kg})\end{array}$ & 0.67 & 0.29 & 0.14 & 0.39 & 0.15 & 0.86 & 0.50 & 0.32 & 0.09 & 0.23 \\
\hline $\begin{array}{l}\text { Zearalenone } \\
(\mu \mathrm{g} / \mathrm{kg})\end{array}$ & 50 & 50 & 50 & 50 & 50 & 50 & 50 & 50 & 50 & 50 \\
\hline
\end{tabular}


Table 3: Concentrations of aflatoxin B1, fumonisin B1, ochratoxin A and zearalenone detected in rice samples, $(\mathrm{n}=10)$

\begin{tabular}{|l|l|l|l|l|l|l|l|l|l|l|}
\hline \multirow{2}{*}{ Mycotoxins } & \multicolumn{10}{|c|}{ Rice samples } \\
\cline { 2 - 11 } & 1 & 2 & 3 & 4 & 5 & 6 & 7 & 8 & 9 & 10 \\
\hline $\begin{array}{l}\text { Aflatoxin } \\
\text { B1, }(\mu \mathrm{g} / \mathrm{kg})\end{array}$ & 1.5 & 1.5 & 5 & 10 & 1.5 & 10 & 1.5 & 5 & $<1.5$ & $<1.5$ \\
\hline $\begin{array}{l}\text { Fumonisin } \\
\mathrm{B} 1,(\mathrm{mg} / \mathrm{kg})\end{array}$ & \multicolumn{8}{|c|}{ Not detected } \\
\hline $\begin{array}{l}\text { Ochratoxin } \\
\mathrm{A}(\mu \mathrm{g} / \mathrm{kg})\end{array}$ & 0.91 & 0.68 & 0.53 & 0.20 & 0.92 & 0.16 & 0.50 & 0.20 & 0.9 & 0.16 \\
\hline $\begin{array}{l}\text { Zearalenone, } \\
(\mu \mathrm{g} / \mathrm{kg})\end{array}$ & 50 & 50 & 200 & 50 & 50 & 200 & 50 & 50 & 50 & 50 \\
\hline
\end{tabular}


Table 4: Concentrations of aflatoxin B1, fumonisin B1, ochratoxin A and zearalenone detected in peanuts samples, $(n=10), n d=$ not detected

\begin{tabular}{|l|l|l|l|l|l|l|l|l|l|l|}
\hline \multirow{2}{*}{ Mycotoxins } & \multicolumn{10}{|c|}{ Peanuts samples } \\
\cline { 2 - 12 } & 1 & 2 & 3 & 4 & 5 & 6 & 7 & 8 & 9 & 10 \\
\hline $\begin{array}{l}\text { Aflatoxin } \\
\text { B1, }(\mu \mathrm{g} / \mathrm{kg})\end{array}$ & 1.5 & 5 & 5 & 5 & 5 & 1.5 & 5 & 5 & 5 & 10 \\
\hline $\begin{array}{l}\text { Fumonisin } \\
\mathrm{B} 1,(\mathrm{mg} / \mathrm{kg})\end{array}$ & $<0.3$ & $<0.3$ & $<0.3$ & $<0.3$ & 6 & 6 & 3 & nd & nd & nd \\
\hline $\begin{array}{l}\text { Ochratoxin } \\
\mathrm{A}(\mu \mathrm{g} / \mathrm{kg})\end{array}$ & 0.26 & 0.56 & 0.20 & nd & nd & nd & nd & 0.64 & 0.25 & 0.33 \\
\hline $\begin{array}{l}\text { Zearalenone, } \\
(\mu \mathrm{g} / \mathrm{kg})\end{array}$ & 50 & 50 & 200 & 50 & 50 & 200 & 50 & 50 & 50 & 200 \\
\hline
\end{tabular}




\title{
CO-OCCURRENCE OF AFLATOXIN $B_{1}$, FUMONISIN $B_{1}$, OCHRATOXIN A AND ZEARALENONE IN CEREALS AND PEANUTS IN COTE D'IVOIRE
}

\author{
SANGARE-TIGORI, Béatrice ${ }^{1,2}$, MOUKHA, Serge ${ }^{1,3}$, KOUADIO, H.James ${ }^{1}$, BETBEDER, \\ ${ }^{1}$ Anne-Marie, DANO, Djédjé Sébastien, ${ }^{2}$ CREPPY, E. Edmond ${ }^{1 *}$ \\ ${ }^{1}$ Dept of Toxicology, University of Bordeaux 2, 146, rue Léo-Saignat, 33076 Bordeaux, \\ France \\ ${ }^{2}$ UFR des Sciences Pharmaceutiques et Biologiques d'Abidjan,University of Cocody, BPV34 \\ Abidjan, Côte d'Ivoire. \\ ${ }^{3}$ INRA-MycSA, P.B. 81, 33883 Villenave d'Ornon, France.
}

\begin{abstract}
*Corresponding author: Prof. E.E.CREPPY, Dept of Toxicology, University of Bordeaux 2, 146, rue Léo-Saignat, 33076 Bordeaux, France. E-mail: edmond.creppy@tox.u-bordeaux 2.fr.
\end{abstract}

\begin{abstract}
:
The present survey examined 30 samples of rice $(n=10)$, maize $(n=10)$ and peanuts $(n=10)$ from Côte d'Ivoire for aflatoxin $\mathrm{B}_{1}$, fumonisin $\mathrm{B}_{1}$ and zearalenone using immunoassays, and ochratoxin A using a validated HPLC method with fluorescence detection. Similarly to some other countries it appeared that in Côte d'Ivoire several mycotoxins are present in the same commodities. These mycotoxins are from different structural families: aflatoxin $\mathrm{B}_{1}$, fumonisin $\mathrm{B}_{1}$, zearalenone, and ochratoxin $\mathrm{A}$. There are normally produced by fungal species from Aspergillus, Penicilium and Fusarium genera. Some samples contained four mycotoxins $(86 \%)$. Four peanuts samples did not show ochratoxin A $(14 \%)$ whereas they contained aflatoxin $\mathrm{B}_{1}$ concentrations, above the EU regulatory limits. The concentrations of ochratoxin $A$, zearalenone and fumonisin $B_{1}$ were low and may not cause problem per se however fears remain that the tolerable daily intake might be exceeded due to eating habits and that synergistic effects might be important with the combination of several mycotoxins. Investigations in this direction are underway together with isolation and characterization of fungal species involved.
\end{abstract}


Keywords: aflatoxin $\mathrm{B}_{1}$, fumonisin $\mathrm{B} 1$, zearalenone, ochratoxin $\mathrm{A}$, co-occurrence, Côte d'Ivoire.

\section{Introduction}

The European Union (EU) has established regulatory limits for mycotoxins in crops and foodstuffs, (EU Commission Directive, 2005) this implies that crops exported from any country to Europe have to be analysed for mycotoxins. In Côte d'Ivoire, a preliminary survey conducted by us showed the presence of ochratoxin A in maize, millet rice and peanuts (Sangare-Tigori et al., 2005). Other authors have found aflatoxins in several foods samples, IARC, 1993; Creppy, 2002a). The question was then; do we have multi-mycotoxin contamination in Côte d'Ivoire? The present study aimed to determine the presence and levels of ochratoxin A, aflatoxins, fumonisins and zearalenone in cereals (maize and rice) and peanuts in order to give an answer to the above question.

\section{Materials and methods}

\section{Samples}

Every time the samples were taken according to the state of the art, with four identical sampling sizes at four different levels of each bulk (top to bottom). Five kg samples were taken each time and mixed to form the sample for analysis. $5 \mathrm{~kg}$ from the mixture of $20 \mathrm{~kg}$ were ground and $200 \mathrm{~g}$ of powder were taken after cautious homogenization of the samples, which were then stored at $-20^{\circ} \mathrm{C}$ until subsequent extraction and analysis. Maize, rice and peanuts were obtained from markets in Abidjan, Côte d'Ivoire, especially in Adjamé, Abobo and Treichville. These markets represent the significant areas which provide feeds to other markets in Côte d'Ivoire.

Samples for analysis were assigned a number from 1 to 10 for each type of foodstuffs. Each sample was composed of five sub-samples of equal size of $5 \mathrm{~kg}$ mixed carefully prior to 
grinding. Thus a tochratoxin $\mathrm{Al}$ of 50 samples were analysed simultaneously for each type of foodstuffs. All the samples were taken from locally produced crops by the end of November 2002, they were stored at $-20^{\circ} \mathrm{C}$ and analysed from January 2003 .

\section{Chemicals}

Toluene (Prolabo), HPLC-grade methanol (Scharlau), HPLC-grade acetonitrile (Scharlau), glacial acetic acid (Chromanorm-Prolabo), anhydrous magnesium chloride approx.98\% (Sigma), sodium acetate (Merck) and hydrochloric acid( Prolabo) were all provided by Merck Eurolab France. Ultrapure water, MilliQ R Plus was obtained using Millipore (France) system in tandem with USF ELGA Prima (France) system. Sep-Pak Plus Silica Cartridges were from Waters (France) (3 cm long, $1 \mathrm{~cm}$ diameter). Ochratoxin A was purchased from SigmaAldrich (USA). The standard solutions of ochratoxin A were made in methanol according to the concentration established using a UV spectrophotometer $(=5500 \mathrm{~mol}-1 \mathrm{~cm}-1)$. The required quantity was evaporated to dryness and dissolved in the mobile phase indicated under chromatographic conditions.

OCHRATOXIN A was assayed by an HPLC method with fluorescence detection and the others mycotoxins by immunoassays (Rhône Diagnostic Technologies, France).

Each sample of rice, maize and peanut was analysed separately for each family of mycotoxin. Four different extracts were obtained for ochratoxin $A$, aflatoxin $B_{1}$, fumonisin $B_{1}$ and zearalenone, (Abdelhamid, 1990, Wood, 1992, Shephard et al. 1996, Scott 2002, Creppy 2002a).

\section{Apparatus}


The rotatory evaporator, Heidolf WB 2000, was from Prolabo (France). The chromatographic system consisted of a Bischoff pump Model A 2200 and an Alcott Autosampler Model RF551 Fluorescence Monitor. To measure the peak area, a PIC3 ® software from ICS was used. A pre-packed stainless steel column( 250 x $4.6 \mathrm{~mm}$ ) with $10 \mu \mathrm{m}$ Spherisorb ODS1 and a guard column ( $30 \times 4.6 \mathrm{~mm}$ ) packed with $10 \mu \mathrm{m}$ Lichrosorb C-18 were used.

\section{Extraction and purification of OCHRATOXIN A:}

A solution containing $10 \mathrm{~g}$ of mixed ground sample, $50 \mathrm{ml}$ of $0.4 \mathrm{M} \mathrm{MgCl}_{2}$ and $30 \mathrm{ml}$ of $2 \mathrm{~N}$ hydrochloric acid were extracted twice with $50 \mathrm{ml}$ of toluene. The two phases were separated by centrifugation $(5 \mathrm{~min}$ at $3000 \mathrm{~g}$ ). The organic phase was evaporated to dryness under vacuum and evaporated extract was dissolved in $1 \mathrm{ml}$ of methanol and loaded onto the cartridge. The cartridge was then washed with $10 \mathrm{ml}$ toluene-acetic acid (90:10; v/v). The flow rate during washing and elution of the Sep Pak cartridge was maintained at $1 \mathrm{ml} / \mathrm{min}$. The elute was evaporated to dryness and dissolved in $1 \mathrm{ml}$ of the mobile phase (Ospital et al.,1998).

\section{Chromatographic conditions for ochratoxin A:}

The mobile phase $(0.45 \mu \mathrm{m}$ filtered and degassed) consisted of $48 \%$ acetonitrile and $52 \%$ $4 \mathrm{mM}$ sodium acetate acetic acid $(19: 1 \mathrm{v} / \mathrm{v})$. The flow rate was $1 \mathrm{ml} / \mathrm{min}$, the column was at room temperature and the injection volume was $50 \mu 1$. The run time for one cycle was $12 \mathrm{~min}$, fluorescence detection wavelengths were excitation $330 \mathrm{~nm}$ and emission $470 \mathrm{~nm}$. The retention time of OCHRATOXIN A under the conditions described was approximately 7 min. Analytical data were collected stored and processed using the PIC 3 software developed by ICS. The quantification of OCHRATOXIN A was achieved automatically by the computer according to the areas under the curve of four standard solutions in the range of $0.6 \mathrm{ng} / \mathrm{ml}$ to 
$60 \mathrm{ng} / \mathrm{ml}$ of OCHRATOXIN A, run sequentially, during the course of analysis. They were linearly related to the amount of OCHRATOXIN A injected. The correlation coefficient was always between 0.997 and 0.998 .

\section{OCHRATOXIN A confirmation}

Out of the $1 \mathrm{ml}$ final extract, $0.5 \mathrm{ml}$ was evaporated to dryness and $0.4 \mathrm{ml}$ of the buffer $0.04 \mathrm{M}$ Tris in $1 \mathrm{M} \mathrm{NaCl}$ adjusted to $\mathrm{pH} 7.5$ with $\mathrm{HCl}$ was added to the evaporated extract. To this solution $100 \mu \mathrm{l}$ of carboxypeptidase (Sigma, Ref C-0261, $100 \mathrm{U} / \mathrm{ml}$ ) was added and the mixture incubated for $3 \mathrm{~h}$ at $37^{\circ} \mathrm{C}$. Fifty $\mu \mathrm{l}$ of this solution was injected into the chromatographic system for separation and quantification of OT alpha, under the same conditions as described for OCHRATOXIN A. The quantification of OT alpha was achieved automatically by the computer according to the areas under the curve of five standards of OT alpha (elution time 5.1min). All the positive samples were confirmed using this procedure that shows moreover disappearance of the peak of OCHRATOXIN A..

\section{Other toxins:}

Aflatoxins, fumonisin and zearalenone were purchased from Sigma-Aldrich (USA). They were dissolved in methanol and utilized similarly to the standards solutions provided with the kits.

\section{Aflatoxin $B_{1}$}

AFLAPLATE ${ }^{\circledR}$ (Rhône Diagnostics, France) was used. It is an immunoassay based on a direct competition ELISA provided with multi-wells plates. It is a very specific, sensitive and 
fast test. The reaction with antibody develops a colour inversely proportional to the concentration of aflatoxin $\mathrm{B}_{1}$. The development of the colour is stopped by $1 \mathrm{~N}$ sulfuric acid solution and the absorbance of each sample measured at $450 \mathrm{~nm}$ in a plate reader.

\section{Fumonisin $\mathbf{B}_{1}$}

FUMONIPLATE ® (Rhône Diagnostics, France) was used to assayed fumonisin $\mathrm{B}_{1}$.

\section{Zearalenone}

ZEARAPLATE ® (Rhône Diagnostics, France) was used to assayed zearalenone. It is similar to AFLAPLATE $®$ or FUMONIPLATE $®$, but highly specific to zearalenone.

\section{Quality control}

Each matrix analysed in this survey was used for validation, i.e. ochratoxin A and aflatoxin $\mathrm{B}_{1}$ free maize, rice, peanuts were spiked in the ranges of regulatory limits up to three times these limits and extracted afterward to evaluate the recovery rates. This was in addition performed three times for each matrix using uniformly tritiated toxins (isotopic mixture 1/1000 with a minimum of $1 \mu \mathrm{Ci} /$ assay). However, higher concentration of ZEA and fumonisin $\mathrm{B}_{1}, 10,40$ 80 and $100 \mu \mathrm{g} / \mathrm{kg}$, were used to spiked toxins free matrixes that were extracted afterwards.

For every five samples of cereals and peanuts, OCHRATOXIN A-free foods provided in France and previously analysed for the mycotoxins concerned were spiked with OCHRATOXIN A at levels of $0.2 ; 0.6 ; 2 ; 6 ; 20 ; 40$ and $60 \mathrm{ng} / \mathrm{g}(\mu \mathrm{g} / \mathrm{kg})$ were extracted and analysed sequentially. The recovery was in the range of 85 to $95 \%$ for peanuts and 90 to $95 \%$ 
for maize and rice samples. This was confirmed by using $\left[{ }^{3} \mathrm{H}\right]-\mathrm{OCHR}$ AOXIN A randomly during the course of extractions, at least one time for each matrix $(n=5)$

Similar quality control was performed for the other toxins without radioactivity however. The recoveries were in the range of 89 to $99 \%$ for aflatoxin $\mathrm{B}_{1}$ (spiked at levels of $1.5,5,10$ and $20 \mu \mathrm{g} / \mathrm{kg}$ ) and zearalenone (spiked at levels of $20,50,200$, and $500 \mu \mathrm{g} / \mathrm{kg}$ ) and 85 to $95 \%$ for fumonisin $B_{1}$ (spiked at levels of $0.3,0.5,1.5$ and $3 \mathrm{mg} / \mathrm{kg}$ ).

Negative control samples from toxin-free crops samples were routinely analysed along with spiked samples

\section{Statistical analysis of data}

Results are presented as individual values in $\mu \mathrm{g} / \mathrm{kg}$ (ppb) for each type of matrix. For the same mycotoxin, concentrations are compared to those found in different matrix. In order to evaluate the contribution of each matrix in human contamination, all individuals values were compared from one matrix to the other using the non-parametric Wilcoxon Rank Sum Test 21 (WRST) with $\mathrm{p}$ fixed at $\mathrm{p}=0.01$.

\section{Results and Discussion}

Concerning matrix effects, the lowest recovery was always obtained for peanut samples $(n=10)$, whereas the highest was obtained for rice and maize, $80 \pm 5 \%$ in peanuts and $98 \pm 3 \%$ for OCHRATOXIN A, fumonisin $\mathrm{B}_{1}$, aflatoxin $\mathrm{B}_{1}$ and zearalenone. The mycotoxins assayed were all detected at variable levels in most of the samples. The main results are summarized in Table 1. The different concentrations of mycotoxins in each type of foodstuffs are given in details in Table 2, Table 3 and Table 4 for respectively maize, rice and peanuts. It appears that 
the contribution for mycotoxins exposure is due in decreasing order to maize $>$ peanuts $>$ rice $(\mathrm{p}=0.01)$

\section{Maize contamination by ochratoxin A:}

In a previous survey ochratoxin A was detected in cereals, millet, maize and rice and in peanuts from Côte d'Ivoire (Sangare-Tigori et al., 2005). The present data thus confirm that ochratoxin A is a frequent contaminant of foodstuffs in this country. All maize samples were ochratoxin A-contaminated and the concentrations ranged from 0.09 to $0.86 \mu \mathrm{g} / \mathrm{kg}$, Table 2 . These concentrations are far less than those found formerly (Dem 1999; Creppy, 2002b). Ochratoxin A concentrations in the range of 27 to $57 \mu \mathrm{g} / \mathrm{kg}$ were found in 1998 in cereal samples including rice. At present ochratoxin A in rice ranges from 0.16 to $0.92 \mu \mathrm{g} / \mathrm{kg}$ (Table 1). The statistics of Côte d'Ivoire show that the total rainfalls in 1998 were of about $1512 \mathrm{~mm}$ versus 1933 mm in 2002 in Abidjan city. The climate in Abidjan city in 2002 was clearly rainier than in 1998 but the harvest period was much drier. This could not explain why maize samples collected in 1998 were unexpectedly more contaminated than samples collected in 2002. The discrepancy between ochratoxin A concentrations in 2002 compared to 1998 can be explained by several reasons linked to political troubles in Côte d'Ivoire. Storage could have been for shorter time before sampling as compared to 1998, influencing other known factors in mycotoxins production such as integrity of grains, rate of fungal growth, prevalence of toxinogenic species, interactions with micro organisms and insects as suggested (Beti et al., 1995). We just do not know the most relevant reason for this low OCHRATOXIN A contamination in the year 2002. But, we suspect that in 2002 the cereal traders imported from neighbour countries maize usually found and eaten locally. This is actually in line with information given by the ministry of agriculture and the ministry of trade in 2003 , which also indicated that freshly imported yellow corn was available for human consumption. This 
yellow corn was not available in market because it was directly distributed to populations in need.

\section{Rice contamination by ochratoxin A:}

Rice samples of the year 2002 (November) were analysed for ochratoxin A and the concentration ranged from 0.16 to $0.912 \mu \mathrm{g} / \mathrm{kg}$ with an overall mean value of $0.44 \pm 0.032$. These values are lower than those reported (Abdelhamid 1990) from Egypt where several samples of foods, including rice, had been assayed and ochratoxin A was found at concentrations ranging from 4 to $577 \mu \mathrm{g} / \mathrm{kg}$ with an average of $58.2 \pm 22.9 \mu \mathrm{g} / \mathrm{kg}$.

\section{Peanuts contamination by ochratoxin A:}

In four peanuts samples, ochratoxin A was not detected at the limit of detection of the method. Ochratoxin A concentrations ranged from 0.203 to $0.642 \mu \mathrm{g} / \mathrm{kg}$ in the other samples (Table 4). In Tunisia for example, ochratoxin A contaminations ranged from 5 to $46000 \mu \mathrm{g} / \mathrm{kg}$ (Bacha et al., 1999). Tunisia has a warm and humid climate that favours fungal development especially because peanuts are stored for long periods since Tunisia does not produce peanuts. This could explain extremely high values such as $46000 \mu \mathrm{g} / \mathrm{kg}$ in this country.

In fact ochratoxin A production depends on conditions of humidity and temperature (Pitt, 1987). The optimal temperature of ochratoxin A production by Aspergillus ochraceus is $28^{\circ}$. This production decreases at $15^{\circ}$ or $37^{\circ}$ (Trenk et al., 1991). Besides, Penicillium verrucosum formerly viridicatum grows at temperatures ranging from 4 to $30^{\circ}$ with water activity of about 22\% (Mislivec et al., 1970; Pitt, 1987). In winter times this large variation of temperature may be encountered in Tunisia rendering the situation more favourable to fungi adapted to these conditions. It is then assumed that ochratoxin A is more produced in winter times by 
Penicillia in Tunisia and in Europe and that in continuously warm regions like Côte d'Ivoire OCHRATOXIN A is produced by Aspergilli mainly (Pohland et al., 1992 and Varga et al., 1996). Thus, combination of all these factors may explain the high concentrations exceptionally found in Tunisia.

After confirmation of the presence of ochratoxin A in most of the samples let us examine the case of other mycotoxins, successively aflatoxin $\mathrm{B}_{1}$, fumonisin $\mathrm{B}_{1}$ and zearalenone.

\section{Aflatoxins}

\section{Aflatoxins in maize:}

Maize samples were contaminated by aflatoxin $B_{1}$ and the levels ranged from $<1.5 \mu \mathrm{g} / \mathrm{kg}$ to $20 \mu \mathrm{g} / \mathrm{kg}$, Table 2. These values are similar to those reported in foodstuffs from Egypt (3 to $12 \mu \mathrm{g} / \mathrm{kg}$ ), from Europe and Tunisia (11.5- $180 \mu \mathrm{g} / \mathrm{kg}$ ) in corn, wheat, oats, and, corn and barley from Korea (Abdelhamid, 1990, Bacha et al., 1999; Scudamore and Patel, 2000; Creppy, 2002a; Park and Troxell, 2002). These values are interestingly in the range of those reported from a very similar west-African country from the viewpoint of the climate, Bénin, (Bouraïma et al, 1993).

\section{Rice contamination by aflatoxins:}

Aflatoxin $B_{1}$ concentrations ranged from $<1.5 \mu \mathrm{g} / \mathrm{kg}$ to $10 \mu \mathrm{g} / \mathrm{kg}$ in rice samples, Table 3 . According to the EU regulatory limits for aflatoxin $\mathrm{B}_{1}$ four of these samples (40\%) would not be accepted for human consumption. Aflatoxin $\mathrm{B}_{1}$ belongs to the mycotoxins family the most studied in the world. In an eastern African country like Kenya, rice may be contaminated at levels ranging from 294 to $1050 \mu \mathrm{g} / \mathrm{kg}$ (Jelinek et al., 1989, IARC, 1993, Creppy et al., 2002a). In USA, aflatoxin B1 contamination in rice was about $280 \mu \mathrm{g} / \mathrm{kg}$, in India, $180 \mu \mathrm{g} / \mathrm{kg}$, 


\section{Peanuts contamination by aflatoxin $B_{1}$ :}

Ten samples of peanuts from Côte d'Ivoire were assayed for aflatoxins and results showed that aflatoxin $B_{1}$ concentrations ranged from 1.5 to $10 \mu \mathrm{g} / \mathrm{kg}$, Table 4 . All the peanuts samples were contaminated with an average of $4.8 \mu \mathrm{g} / \mathrm{kg}$. These concentrations are similar to those found in Egypt: 3 to $12 \mu \mathrm{g} / \mathrm{kg}$, (Abdelhamid, 1990) and were far less than those encountered in Sudan, 250 g/kg, (Jelinek et al., 1989; Bacha et al., 1999; Scudamore et al., 2000; Creppy, 2002a; Park and Troxell, 2002).

Aflatoxins are produced by at least three fungal species including, Aspergillus flavus which produces aflatoxins $\mathrm{B}_{1}$ and $\mathrm{B}_{2}$ and Aspergillus parasiticus which produces all four alfatoxins $\mathrm{B}_{1}, \mathrm{~B}_{2}, \mathrm{G}_{1}$ and $\mathrm{G}_{2}$ and Aspergillus niger. The dryness, temperature, type of grain and their contaminants may influence the growth of the mould. After the harvest, the conditions of storage and transportation of grains or foods may enhance aflatoxin $\mathrm{B}_{1}$ concentrations suddenly. The most favourable conditions for growth and production aflatoxins by A. flavus are quite similar to that leading to production of ochratoxins by A ochraceus, aliaceus or other Aspergilli (Christensen et al., 1973). It is thus not surprising that most of samples collected in the present survey are contaminated by aflatoxin $\mathrm{B}_{1}$ and ochratoxin $\mathrm{A}$. 


\section{Fumonisins}

All maize, rice and peanuts samples were analysed for fumonisin $B_{1}$.

\section{Maize contamination by fumonisin $B_{1}$ :}

All the samples were contaminated and the concentrations ranged from 0.3 to $1.5 \mu \mathrm{g} / \mathrm{kg}$ with a mean value of $0.9 \mu \mathrm{g} / \mathrm{kg}$. Fumonisins are the most prevalent mycotoxins in the world (Shepard et al., 1996) and these mycotoxins contaminate essentially maize. The real problem is the fact that maize cobs, although very contaminated, have the appearance of noncontaminated cobs. And some people for example from Transkei in South Africa prefer mouldy maize. Some other people do prefer traditional beers made at home with mouldy maize, because of its particular taste (Norred, 1993). Fumonisins are essentially produced by fungi called Fusarium moniliforme and Fusarium proliferatum and Fusarium culmorum which contaminate the cobs without any physical sign. In South Africa sometimes $100 \%$ of maize samples are found contaminated with maximal concentrations reaching $1890 \mu \mathrm{g} / \mathrm{kg}$ (Sydenham et al., 1994). In Benin, a western African country, 9 of 11 samples of maize were fumonisins-contaminated and the maximal concentrations were $2.3 \mu \mathrm{g} / \mathrm{kg}$ (Doko et al., 1995). In France 23 of 25 samples were contaminated with a maximal concentration of $3.35 \mu \mathrm{g} / \mathrm{kg}$ (De Nijs et al., 1999b). The concentrations found in maize in Côte d'Ivoire are not apparently different from those found in Bénin or in France.

\section{Rice contamination by Fumonisin $\mathbf{B}_{1}$}

Unexpectedly rice samples collected in November 2002 were not contaminated by fumonisin $B_{1}$. No explanation could be given for that at present except that this rice could be a freshly imported one, however some other mycotoxins such as aflatoxin $\mathrm{B}_{1}$ and ochratoxin $\mathrm{A}$ were found. 


\section{Peanuts contamination by fumonisin $B_{1}$}

Only seven samples analysed were found with appreciable concentrations of fumonisin $B_{1}$, Table 4. The concentrations ranged from $<0.3$ to $6 \mu \mathrm{g} / \mathrm{kg}$.

\section{Zearalenone}

Zearalenone, (ZEA) also called F2-toxin, is a non-steroïdal estrogenic mycotoxin produced as a secondary metabolite by several species of Fusarium, particularly F.graminearum or Gibberella zea (Stob et al.,1962), F. semitectum, F.equiseti, F.crookwellense and F.culmorum (IARC, 1993). This mycotoxin may be also produced by F.tricinctum, F.moniliforme, F.oxysporum, F.sporotrichoïdes and F.laterium (Mirocha et al., 1971).

The production of zearalenone by these Fusarium species is favoured by low temperatures ranging from 10 to $15^{\circ}$ (Caldwell et al., 1970) at certain period of fungal infestation of crops. In fact, the maximum of mycotoxin is produced at such low temperatures that are considered stressful to fungi (Sherwood and Peberdy, 1972, 1974). The water activity in grains is also a crucial factor in zearalenone production by Fusarium species. The presence of oxygen is important too, for example F.graminearum cannot grow neither produce zearalenone in anaerobia conditions of storage (Escoula, 1979). For all these reasons and especially because of low temperature required during fungal development on crops the presence of ZEA was questionable in foodstuffs collected in Côte d'Ivoire.

\section{Maize contamination by zearalenone:}

All the maize samples were contaminated by zearalenone at levels up to $50 \mu \mathrm{g} / \mathrm{kg}$, Table 2 . These zearalenone concentrations in maize could not endanger people's health considering zearalenone alone (Castegnaro, 1995). Indeed these concentrations are under the EU 
regulatory limits for zearalenone.

\section{Rice contamination by zearalenone:}

All rice samples were zearalenone-contaminated and the concentrations ranged from $50 \mathrm{ppm}$ to $200 \mu \mathrm{g} / \mathrm{kg}$, Table 3. In France and in Europe, the maximal concentration admitted for human foods and animals feed are $200 \mu \mathrm{g} / \mathrm{kg}$, (Castegnaro, 1995, EU Commission Directive, 2005).

\section{Peanuts contamination by zearalenone:}

All peanuts samples were contaminated by zearalenone and the concentrations ranged from 50 to $200 \mu \mathrm{g} / \mathrm{kg}$. Although zearalenone was detected in samples collected in Côte d'Ivoire, concentrations do not exceed EU regulatory limits and were rather low in cereals produced and commercialized in Côte d'Ivoire. This country is located in western Africa where temperatures being always between 24 to $34^{\circ}$ do not permit Fusarium species to grow and produce zearalenone in large amounts. However it is present and could worsen the toxic effects of other mycotoxins such as aflatoxin $\mathrm{B}_{1}$, ochratoxin $\mathrm{A}$ and fumonisin $\mathrm{B}_{1}$.

The literature already reported cases of combination of ochratoxin and aflatoxin or ochratoxin and fumonisin. Cases of combination of four to five mycotoxins in the same commodities have been reported with combined effects in vivo and/or synergistic effects (Dawlatana et al., 2002; Diaz et al., 2001; Gobel and Lusky, 2004; Park and Troxell, 2002). It is known that combination of mycotoxins in general lead to combined, additive or synergistic effects. This may concern organ toxicity but also carcinogenesis, especially considering aflatoxin $\mathrm{B}_{1}$ and ochratoxin A in the present case, respectively classified in group 1 and $2 B$ by IARC. Since zearalenone is the major mycotoxin implicated in hormonal dysruption, and the nephrotoxic 
ochratoxin A increasingly involved in hormonal disorders, one may fear that whenever zearalenone is combined with ochratoxin $\mathrm{A}$ and/or fumonisin $\mathrm{B}_{1}$ this could enhance hormonal disorders in relation with zearalenone and nephrotoxic effect of ochratoxin A, (Benesic et al., 2000).

Concerning the possibility that this mixture of mycotoxins, some of them being genotoxic such as aflatoxins, ochratoxins and zearalenone, could affect immune response in human, the situation should be carefully evaluated through epidemiological studies. One possibility is the morbidity linked to infectious diseases such as bacterial or viral ones. It is believed that mycotoxins may participate in premature death of children in case of bacterial-induced diarrhoea. In this purpose the childhood seems to be a crucial period when the food available should be preserved from high contamination since this may worsen malnutrition, kwachiorkor and possible Reye's syndrome. It seems to be a valuable duty to survey for these diseases and to determine the severity of malnutrition and human exposure to mycotoxins mainly for pregnant women and children during the period of lactation since several toxins including those detected in the present study are known to contaminate breast milk of exposed people. The fungi that produce the mycotoxins detected should be further isolated cultured and characterized by mycologists.

The weekly diet of inhabitants of Cote d'Ivoire contains approximately $500 \mathrm{~g}$ of maize, $3 \mathrm{~kg}$ of rice and $150 \mathrm{~g}$ of peanuts. Using data in table1 the weekly intake can be calculated for aflatoxin $\mathrm{B}_{1}$, ochratoxin $\mathrm{A}$, fumonisin $\mathrm{B}_{1}$ and zeralenone which are $41.5 \mu \mathrm{g}$ (Daily Intake, $\mathrm{DI}=$ $99 \mathrm{ng} / \mathrm{kg}$ bw/day), $3.29 \mu \mathrm{g}(\mathrm{DI}=7.8 \mathrm{ng} / \mathrm{kg}$ bw/day), $1.65 \mathrm{mg}(\mathrm{DI}=3.9 \mu \mathrm{g} / \mathrm{kg}$ bw/ day) and 655 $\mu \mathrm{g}(\mathrm{DI}=1.56 \mu \mathrm{g} / \mathrm{kg}$ bw/day) respectively. These features appear to be largely above the tolerable daily intake set by WHO for respectively aflatoxins $(<1 \mathrm{ng} / \mathrm{kg}$ bw/day $)$, fumonisin 
B 1 (2 $\mu \mathrm{g} / \mathrm{kg}$ bw/day) and zearalenone (500 ng/ kg bw/day), JECFA 1999, JECFA 2001.

\section{Conclusions}

The combinations of the four mycotoxins assayed in commodities consumed almost daily endanger people's health. This study reveals that mycotoxins multi-contamination occurs in Côte d'Ivoire in most of maize, rice and peanuts samples collected by the end of November 2002, in which ochratoxin $A$, aflatoxin $B_{1}$, fumonisin $B_{1}$ and zearalenone were found in appreciable amounts, some of which exceeded EU regulatory limits such as aflatoxin $B_{1}$ that mostly poses problems. This situation is expected to occur in tropical countries and suggests that the crops analysed may have been produced in this geographical area. The calculation of daily intake with the highest concentrations found shows that fumonisin $\mathrm{B}_{1}$ and zearalenone are also of concern due to eating habits although found at concentrations below regulatory limits. The main question is at present what health hazard could be linked to this cooccurrence of aflatoxin $\mathrm{B}_{1}$, ochratoxin $\mathrm{A}$, fumonisin $\mathrm{B}_{1}$ and zearalenone? Further investigations are under way.

\section{References}

Abdelhamid,A.M., 1990, Occurrence of some mycotoxins (aflatoxin, ochratoxin A, citrinin, zearalenone and vomitoxin) in various Egyptian feeds. Arch Tierernahr, 40, 647-664.

Bacha,H., Maaroufi,K., Ghedira-Chekir,L., Abid, S., Cherif, A., Achour, A., Creppy,E.E., 1999, Mycotoxins and mycotoxicosis in Tunisia: what do we know and what do we need to know? J. Toxicol-Toxin Reviews, 18 (3\&4), 245- 262. 
Benesic,A., Mildenberger, S., Gekle, M., 2000, Nephritogenic ochratoxin A interferes with hormonal signalling in immortalized human kidney epithelial cells. Pflugers Arch, 439, 278287.

Beti JA, Phillips TW, Smalley EB., 1995, Effects of maize weevils (Coleoptera:

Curculionidae) on production of aflatoxin B1 by Aspergillus flavus in stored corn. J Econ Entomol. 88, 1776-1782.

Bouraïma, Y., Ayi-Fanou, L., Kora, I., Sétondji, J., Sanni, A., Creppy, E.E., 1993, Mise en evidence de la contamination des cereals par les aflatoxines et l'ochratoxine A au Bénin. In Creppy,E.E., Castegnaro, M., Dirheimer,G. (Eds.). Colloque INSERM/ John Libbey Eurotext Human Ochratoxicosis and its Pathologies, 231, 101-110.

Caldwell, R.N., Tuite, J., Stob, M., Baldwin, R., 1970, Zearalenone production by Fusarium species. Appl. Microbiol., 20, 31-37.

Castegnaro M., 1995, Les mycotoxines: des contaminants omniprésents dans l'alimentation humaine et animale, risqué et prevention. In : Sécurité alimentaire du consommateur. Moll M, Moll N eds (Paris, New York, Lavoisier Tec\&Doc), 55-83.

Christensen, C.M., Nelson, G.H., Speers, G.M., Mirocha, C.J., 1973, Results of feeding tests with rations containing grain invaded by a mixture of naturally present fungus plus Aspergillus flavus. Feedstuffs, NRRL 2999, 20-41.

Creppy,E.E., 2002, Update of survey, regulation and toxic effects of mycotoxins in Europe. Toxicol. Lett., 127, 19-28. 
Creppy, E.E., 2002, Ochratoxin A in Côte d'Ivoire. Personal communication.

Dawlatana, M., Coker, R.D., Nagler, M.J., Wild, C.P., Hassan, M.S., Bluden, G., 2002, The occurrence of mycotoxins in key commodities in Bengladesh: surveillance results from 1993 to 1995. J. Nat. Toxins, 11, 379-386.

De Nijs, M., Sizoo, E.A., Rombouts, F.M., van Egmond, H.P., 1998 b, Fumonisin B1 in maize food production imported in the Netherlands. Food Addict. Contam., 15, 389-392.

Dem, A.A., 1999, Contribution à l'étude des mycotoxines en Côte d'Ivoire : recherche et dosage de l'ochratoxine A dans les céréales. Pharmacist Doctorate thesis, University of Cocody Abidjan, $\mathrm{N}^{\circ} 435$.

Diaz, C.T., Sogbe, E., Ascanio, E., Hernandez, M., 2001, Ochratoxin A and fumonisin B1 natural interaction in pigs. Clinical and pathological studies. Rev. Cient-Fac. Cien, 11, 314321.

Doko, M.B., Rapior, S., Visconti, A., Schjoth, J.E., 1995, Incidence of levels of fumonisins in contamination in maize genotypes grown in Europe and Africa. J. Agric. Food Chem 43 , $429-434$.

Escoula, L., 1979, Fusarium graminearum dans les ensilages. Production de zéaralenone. Ann. Rech. Vet., 10, 615-617. 
EU Commission Directive 2005/5/EC of January 2005 amending Directive 2002/26/EC as regards sampling methods of analysis for the official control of the levels of ochratoxin A in certain foodstuffs. Official Journal L 027, 38-40.

Gobel, R., Lusky, K., 2004, Simultaneous determination of aflatoxins, ochratoxin A and zearalenone in grains by new immunoaffinity column/liquid chromatography. J AOAC Int, 87(2), 411-416.

IARC, 1993, IARC Monographs on the Evaluation of Carcinogenic Risks to Humans: some naturally occurring substances: food items and constituents, heterocyclic aromatic amines and mycotoxins. Lyon, 56, 397-444.

JECFA, 1999, Evaluation of certain food additives and contaminants. $49^{\text {th }}$ Report. Technical report Series number 884, Geneva:WHO, pp 69-77.

JECFA, 2001, Safety evaluation of certain mycotoxins in food. Prepared by the $56^{\text {th }}$ meeting of the joint FAO/WHO expert committee on food additives. Report. Food additive Series number 47, Geneva:WHO.

Jelinek, C.F., Pohland, A.E., Wood, G.E., 1989, Review of mycotoxin contamination. Worldwide occurrence of mycotoxins in foods and feeds an update. J. Assoc. Off. Anal. Chem., 72, 223-230. 
Mirocha, C.J., Christensen, C.M., Nelson, G.H., 1971, F-2 (zearalenone) estrogenic

mycotoxin from Fusarium. In: Kadis, S., Ciegler, A., Ajl, S.J. eds. Microbila toxins, 7, $107-$ 138.

Mislivec, P.B., Tuite, J, 1970, Temperature and relative humidity requirements of species of Penicillium isolated from yellow dentcorn kernels. Mycologia, 62, 75-88.

Norred, W.P., 1993, Fumonisins-Mycotoxins produced by Fusarium moliniforme. J. Toxicol. Environ. Health, 38, 309-328.

Ospital, M., Cazabeil, J-M., Betbeder, A-M., Tricard, C., Creppy, E.E., Medina, B., 1998, Ochratoxine A dans les vins. Revue française d'Oenologie, 169, 16-69.

Park, D.L., Troxell, T.C., 2002, US perspective on mycotoxin regulatory issues. Adv. Exp. Med. Biol., 504, 277-285.

Pitt, J.I., 1987, Penicillium viridicatum, Penicillium verrucosum and production of ochratoxin A. Appl. Environ. Microbil., 53, 266-269. 

64, 1029-1046.

Primature Côte d'Ivoire/ BNETD/ Observatoire Agrométéorologique Cellule de Coordination Nationale Données Pluviométriques Abidjan ( secteur Anyama), 2004, Relevés des années 1998 à 2002.

Sangare-Tigori, B., Dem, A.A., Kouadio, H.J., Betbeder, A-M., Baudrimont, I., Dano, D.S., Moukha, S., Creppy, E.E., 2005, Preliminary survey of ochratoxin A in millet, maize, rice and peanuts in Côte d'Ivoire from 1998 to 2002.Revised version submitted to Hum. Exp. Toxicol. August 2005. 
Scott, P. M., 2002, Methods of analysis for ochratoxin. Adv Exp Med Biol, 504, 277-285.

Scudamore KA, Patel S., 2000, Survey for aflatoxins, ochratoxin A, zearalenone and fumonisins in maize imported into the United Kingdom.

Food Addit Contam.,17, 407-416.

Shepard, G.S., Thiel, P.G., Stockenstrom, S., Sydenham, E.W., 1996, Worldwide survey of fumonisin contamination of corn and corned-based products. J. Assoc. Off. Anal. Chem., 79, $671-687$.

Sherwood, R.F., Peberdy, J.F., 1972, Factors affecting the production of zearalenone by Fusarium graminearum in grain. J. Stored Prod. Res., 8, 71-75.

Sherwood, R.F., Peberdy, J.F., 1974, Production of mycotoxin, zearalenone by Fusarium graminearum growing on stored grain. I Grain storage at reduced temperatures. J. Sci. Food Agric, 25, 1081-1087.

Stob, M., Baldwin, R.S., Tuite, J., Andrews, F.N., Gilette, K.G., 1962, Isolation of an anabolic, uterotrophic compound from corn infected with Gibberella zea. Nature , 196, 13-18.

Sydenham, E.W., van der Westhuizen, L., Stockenström, S., Shepard, G.S.,1994, Fumonisin contamination of commercial corn-based human foodstuffs. J. Agric. Food Chem., 39, 20142018. 
Trenk, H.L., Butz, M.E., Chu, F.S., 1991, Production of ochratoxin in different cereal products by Aspergillus ochraceus. Appl. Microbiol , 21, 1032-1035.

Varga, J., Kevei, E., Rimyu, E., Teren, J., Kazakiewicz, Z., 1996, Ochratoxin production by Aspergillus species. Appl. Environ. Microbiol. , 62 , 4461-4464.

Wood, G.E., 1992, Mycotoxins in foods and feeds in the United States. J.Anim Sci. Review, 70 (12),3941 -3949. 